\title{
Teachers' Fairness and Passion for Teaching as Correlates of Secondary School Student Academic Performance in Ekiti State, Nigeria
}

\author{
BOLARINWA Dapo Alonge 1* $^{*}$ OGUNMILADE Johnson Olusesan ${ }^{2}$ \\ OLAOYE Ajiboye Ojo ${ }^{2}$ ABIODUN Eunice Olatide ${ }^{3}$ \\ OLANIYI Oladele Nathaniel ${ }^{2}$ \\ 1.Department of Educational Management, \\ Faculty of Education, Ekiti State University, PMB 5363, Ado-Ekiti, Ekiti State, Nigeria \\ 2.Department of Vocational and Technical Education, \\ Faculty of Education, Ekiti State University, PMB 5363, Ado-Ekiti, Ekiti State, Nigeria \\ 3.Department of Social Science Education \\ Faculty of Education, Ekiti State University, PMB 5363, Ado-Ekiti, Ekiti State, Nigeria
}

\section{Highlights:}

- There was significant relationship between teachers' fairness and secondary school student academic performance.

- There was significant relationship between passion for teaching and secondary school student academic performance.

- Teachers' fairness and passion for teaching had influence on secondary school student academic performance.

\begin{abstract}
The study examined the relationship between teachers' fairness, passion for teaching and secondary school student academic performance in Ekiti State, Nigeria. The purpose of the research is to find out the relationship between teachers' fairness, passion for teaching and secondary school student academic performance. Teachers' Fairness and Passion for Teaching Questionnaire (TFPTQ) and Secondary School Student Academic Performance Inventory (SSSAPI) were used for the study. Descriptive research of the survey type was employed for the study. The study revealed that there was significant positive relationship between teachers' fairness, passion for teaching and secondary school student academic performance. The study had shown that teachers' fairness and passion for teaching had influence on secondary school student academic performance.
\end{abstract}

Keywords: Teachers, Fairness, Academic Performance, Teaching, Teachers' Fairness

DOI: $10.7176 /$ PPAR/9-12-08

Publication date: December $31^{\text {st }} 2019$

\section{Introduction}

Student academic performance means different thing and this has led to a global debate around the concept. According to Achombo (2010), the issue of academic performance at schools has been of concern ever since modern education was introduced. Oluwagbohunmi (2008) observed that the total number of students enrolled at the beginning of secondary education are not always turned out at the completion of the course while tracing the step by step flow of a generation of students through six-year secondary educational circle, it was also observed that as many drop out in the way, some are delayed through one or more repetitions.

The researchers had observed that performance of students in public secondary schools in West African School Certificate Examinations conducted by the West African Examinations Council in Ekiti State had been poor. Olaleye (2011) observed that growing failure rate of students could be noticed in the yearly decline in their performance in the Senior School Certificate. Aboho, Dodo and Isa (2014) observed that the poor academic performance is evidenced in Senior School Certificate Examination which has continued to be on the decline. The researchers observed that the above scenario was persisted up to 2018 WASSCE result in Ekiti State.

The researchers had observed through their wards that teachers failed to give fair treatment to every student. Their wards also complained that some teachers gave preferential treatment to some students; did not give fair hearing to students; favoured some students over others in the distribution of marks; discriminatory in the award of marks and punishment to students.

The researchers also observed from their wards that some teachers were not regular in the class and that such teachers did not make any effort to teach lessons missed because, the passion for teaching was not there. It appears, some of the teachers were not trained because some of them were teaching with non-educational qualifications such as, Bsc, BA, B.Tech and so on. Involuntarily, they found themselves in teaching profession not because of their love for the job but because of the harsh economic situation in Nigeria which has led to high 
unemployment rate. Hence, the passion for teaching may not be there.

In addition, it appears, some male teachers were persuaded by their spouse to go into teaching profession so that they would not stay idle. A person who is forced to take teaching appointment against his or her wish may not have passion for effective teaching. Kanu and Akanwa (2012) confirmed this submission as they observed that some teachers are simply not interested in the service they render. An uncommitted teacher may not be dedicated to duty. Ibukun cited in Akindutire and Ekundayo (2012), regretted that many brilliant individuals are not willing to take up teaching as a profession.

\section{Literature Review}

The term 'academic performance' is the scholastic standing of a student at a given moment. It refers to how an individual is able to demonstrate his or her intellectual abilities. It is the outcome of education, that is, the extent to which an institution achieved its educational goals. According to Popoola (2017), in educational institutions, success is measured by academic performance or how well a student meets the standards set by the examination bodies. Okorie (2014) said, teachers evaluate students in the form of assignment, test and examination to describe how well they have done.

According to Leanderb (1980) cited in Ajayi (2019), fairness is the distribution of rewards and punishment in such a way that justice is done. Rodabaugh (1996) cited in Ajayi (2019) opined that fairness is made up of three components.

1. Interactional Fairness: This is interaction between instructor and students. It encompasses impartiality, respect, concern for students, integrity and propriety.

2. Procedural Fairness: These are rules for grading and classroom administration.

3. Outcome Fairness: This is the distribution of scores and grades.

National Agency for School Evaluation in Lithuania (2014) cited in Grazima and Daiva (2016) in a study titled, "perceived unfairness in teacher-student conflict situations: students' points of view" found out that approximately 20 per cent of students have experienced unfairness in school and that their teachers were unfair in administering punishments and rewards. Dalbert and Stoeber (2006) in their study titled, 'the personal belief in a just world and domain-specific beliefs about justice at school and in the family: a longitudinal study with adolescents." found out that there is a positive relationship between fairness and students' academic performance. Santinello, Vieno and De Vogil (2009) in a study titled, 'primary headache in Italian early adolescents: the role of perceived teacher unfairness" found out that perceived teacher unfairness can significantly predict frequent headaches among early adolescents.

Whitley, Perkins, Balogh, Keith-Spiegel and Wittig (2000) in a study titled, 'fairness in classroom' found out that because fairness is a perception based on interpretations of behaviour, not intentions, many instructors may inadvertently engage in what students perceive to be fair. Tierney (2016) in his study titled, 'fairness in educational assessment' found out that fairness is a moral virtue and a fundamental quality in educational assessment; and that understanding of fairness in educational assessment has evolved with developments in learning theory and measurement and that it has been increasingly been recognised as a necessary quality for inclusivity in education. Pratt (1974) cited in Ajayi (2019) opined that one of the cornerstone supporting a good learning environment is the teacher's use of fair rather than unfair verbal behaviour. He went further that fair verbal behaviour on the part of the teacher is a prerequisite if optimum student learning is to take place.

According to Bamgbola (2004) cited in Alimi and Balogun (2010), love for the job should be seen as the most important attribute of a good teacher and that by loving his/her job, he/she will strive for academic excellence. They went further that teacher must love teaching for its own sake and that the love for the job will influence him/her to do all that is right at the expected time. Oludipe and Oludipe (2004) opined that it will be expected that a person who of his own volition decides to delve into teaching, will be ready to give in his best and operate maximally in his field than someone who was coarsed.

Teachers' on-going commitment and dedication to students and learning has been described by Tugrul (2013) as one of the most important factors in the development of passion for teaching. The researcher said, teachers with passion, work with enthusiasm, their dedication and commitment increase, and they believe in the importance of their job. Olaleye (2011) attributed students' failure in their academic career to lack of teachers' dedication.

\section{Materials and Methods}

One self-designed and an inventory was used for the study. They are, 'Teachers' Fairness and Passion for Teaching Questionnaire" (TFPTQ) and "Secondary School Student Academic Performance Inventory" (SSSAPI).

The descriptive research of the survey type was adopted for the study. The population of the study consisted of 11,991 Senior Secondary School III students and 185 school principals in Ekiti State public secondary schools (Source: Planning, Research and Statistics Department, Ekiti State Teaching Service Commission, Ado-Ekiti, 
Nigeria). The sample for the study was 1,200 students. Multistage sampling procedure was used for the study.

The first stage involved the use of stratified simple random sampling technique to select two Local Government Areas from each of the three Senatorial Districts. The second stage involved the use of simple random sampling technique to select four secondary schools from each of the six Local Government Areas randomly selected and this gives a total of 24 school principals. The third stage involved the use of a simple random sampling technique to select 50 students from each of the 24 secondary schools and this gives a total of 1,200 students. All the 24 school principals of the 24 secondary schools selected in stage two were used for the study.

\section{Results}

The two hypotheses formulated for the study were tested as shown in tables 1 and 2.

Table 1: Test of relationship between teachers' fairness and secondary school student academic performance

\begin{tabular}{|l|l|l|}
\hline Student Academic Performance & N & Per Cent \\
\hline 5 Credits and above & 924 & 41.4 \\
\hline 4 Credits & 472 & 21.1 \\
\hline 3 Credits & 252 & 11.3 \\
\hline Below 3 Credits & 584 & 26.2 \\
\hline Total & 2,232 & 100.0 \\
\hline
\end{tabular}

Table 1 presents the level of secondary school student academic performance. The result shows that 924 representing 41.4 per cent of the total enrolment of students who had five credits, 472 (21.1 per cent) had four credits while 252 (11.3 per cent) had three credits and 584 (26.2 per cent) had below three credits. This implies that the level of secondary school student academic performance is relatively moderate.

Table 2: Test of relationship between teachers' passion for teaching and secondary school student academic performance

\begin{tabular}{|l|l|l|l|l|l|}
\hline \multicolumn{1}{|c|}{ Variables } & $\mathrm{N}$ & Mean & $\mathrm{SD}$ & $\mathrm{r}_{\mathrm{cal}}$ & $\mathrm{r}_{\mathrm{tab}}$ \\
\hline Teachers' passion for teaching & 24 & 16.74 & 0.78 & & \\
\cline { 1 - 4 } Secondary school student academic performance & 24 & 2.93 & 0.83 & $0.52 *$ & \multirow{2}{*}{0.01} \\
\hline
\end{tabular}

$* \mathrm{p}<0.05$ (significant result)

Table 2 shows the relationship between teachers' passion for teaching and secondary school student academic performance. The result obtained from the analysis shows that the value of r-calculated $(0.52)$ is greater than r-table value of (0.01). Therefore, the null hypothesis earlier formulated is rejected. This then means that there is significant positive relationship between teachers' passion for teaching and secondary school student academic performance of students.

\section{Discussion}

The study revealed that there was significant positive relationship between teachers' fairness and secondary school student academic performance. This means that teachers' fairness will enhance the secondary school student academic performance. This may be as a result of display and demonstration of principle of fairness and equity by the teachers to their students irrespective of race, cultural background and gender. This finding agrees with that of Tierrey (2016) who found out that fairness is a normal virtue and a fundamental quality in educational assessment; and that understanding of fairness in educational assessment has evolved with developments in learning theory and measurement and that it has been increasingly been recognised as a necessary quality for inclusivity in education; Dalbert and Stoeber (2006) who found out that there is a positive relationship between fairness and students' academic performance ; and Pratt (1974) cited in Ajayi (2019) who opined that one of the cornerstones supporting a good learning environment is the teacher's use of fair rather than unfair verbal behaviour.

The study also revealed that there was significant positive relationship between teachers' passion for teaching and secondary school student academic performance. This means that teachers' passion for teaching will enhance the secondary school student academic performance. This may be as a result of teachers' dedication to duty. This finding is in support of Bangbola(2004) cited in Alimi and Balogun (2010) who opined that love for the job should be seen as the most important attribute of a good teacher and that by loving his/her job, he/she will strive for academic excellence; Garrison and Liston (2004) who said, those who feel the call to teach, who sense teaching is a profoundly meaningful part of their life, have passion for teaching; Tella (2008) who opined that commitment and dedication to students and learning as one of the most important factors in the development of passion for teaching; and Olaoye (2011) who attributed students' failure in their academic career to lack of teachers' dedication.. 


\section{Acknowledgements}

First and foremost, we sincerely appreciate the teachers and principals sampled in Ekiti State, Nigeria for this study, for their assistance and cooperation during the administration of the instrument. We thank the entire members of Ekiti Teaching Service Commission especially, Planning, Research and Statistics Department for releasing the West African School Certificate results. We acknowledge with thanks and immense gratitude, all the sources cited in this study and the ideas borrowed from published and unpublished sources. We cannot but express our sincere appreciation to Dr Bolarinwa Dapo Alonge for typing and sending the manuscript for reviewing.

We thank the Tertiary Education Trust Fund (TETFund) for providing enough funds for research despite the fact that we were unable to access the funds. May God bless the Agency abundantly (Amen).

\section{REFERENCES}

Aboho, M.R; Dodo, A.E. \& Isa, E.L. (2014). Teacher-student interaction on academic performance: A case of Senior Secondary Economics students in Benue State, Nigeria. Journal of Resourcefulness and Destination, $7(1), 1-16$.

Achombo, C.N. (2010). Factors affecting the performance of pupils in primary schools in Paidhattown Council. Unpublished Masters Dissertation, Makerere University

Ajayi, O.A. (2019). Teacher factors as correlates of secondary school student academic performance in Ekiti State, Nigeria. Unpublished M.Ed Thesis in the Department of Educational Management, Faculty of Education, Ekiti State University, Ado-Ekiti, Nigeria.

Akindutire, I.O. \& Ekundayo, H.T. (2012). Teacher education in democratic Nigeria: Challenges and the way forward. Educational of Research, 3(5), 429-435.

Alimi, O.S. \& Balogun, B.N. (2010). Teachers' attributes as correlates of students' academic performance in Geography in secondary schools in Ondo State, Nigeria. Pakistan Journal of Social Sciences, 7(5), 388-392.

Dalbert, C. \& Stoeber, J. (2006). The personal belief in a just world and domain-specific beliefs about justice at school and in the family: A longitudinal study with adolescents. International Journal of Behavioural Development, 3(3), 200-207.

Garrison, J. \& Liston, D. (2004). Teaching, learning, and loving. New York: Teachers College Press.

Grazima, C. \& Daiva, R. (2016). Perceived unfairness in teacher-student conflict situations: students' points of view. Polish Journal of Applied Psychology, 14 (1), 49-66.

Kanu, S. I. \& Akanwa, U. N. (2012). Unethical practices in the Nigeria educational system. Ijorb.webs.com

Okorie, A. N. (2014). Relationship among peer pressure, time management, and academic performance of inschool adolescents in Umuahia Education Zone, Department of Educational Foundations, Faculty of Education, University of Nigeria, Nsukka, Nigeria.

Olaleye, F. O. (2011). Teachers' characteristics as predictor of academic performance of students in secondary schools in Osun State, Nigeria. European Journal of Educational Studies, 3(3), 505-511.

Oludipe, B. D. \& Oludipe, P. R. (2004). An investigation into the attitude of prospective teachers towards teaching. Journal of Educational Foundations and Management, 4(1), 146-153.

Oluwagbohunmi, M. F. (2008). Repitition and dropout rates in secondary schools in Ikole Local Government Area of Ekiti State, Nigeria (2002-2005). Journal of Educational Foundations and Management, 6(1), 153160.

Popoola, O. B. (2017). Students' personality and teacher leadership styles as correlates of academic performance in Yobe State secondary schools. Unpublished M.Ed Thesis, Department of Educational Management, Faculty of Education, Ekiti State University, Ado-Ekiti, Nigeria.

Santinello, M., Vieno, A. R. \& De Vogli, R. (2009). Primary headache in Italian early adolescents: the role of perceived teacher unfairness. Headache, 49, 366-374.

Tella, A. (2008). Teacher variables as predictors of academic achievement of primary school pupils' Mathematics. International Electronic Journal of Elementary Education, 1(1), 16-33.

Tierney, R. D. (2016). Fairness in educational assessment. M. A. Peters (Eds.) https://www.researchgate,net/publication/30499512.

Tugrul, C. (2013). A passionate teacher: teacher commitment and dedication to student learning. International Journal of Academic Research in Progressive Education and Development, 2(1), 437-442.

Whitley, B., Perkins, D., Balogh, D., Keith-Spiegel, P. \& Wittig, A. (2000). Fairness in classroom . http://www.psychologicalscience.org/teaching/tips/tips 0700.html. 